\title{
Hotspot of glyoxal over the Pearl River delta seen from the OMI satellite instrument: implications for emissions of aromatic hydrocarbons
}

\author{
Christopher Chan Miller ${ }^{1}$, Daniel J. Jacob ${ }^{1,2}$, Gonzalo González Abad ${ }^{3}$, and Kelly Chance ${ }^{3}$ \\ ${ }^{1}$ Department of Earth and Planetary Science, Harvard University, Cambridge MA, USA \\ ${ }^{2}$ School of Engineering and Applied Sciences, Harvard University, Cambridge MA, USA \\ ${ }^{3}$ Harvard-Smithsonian Center for Astrophysics, Cambridge MA, USA
}

Correspondence to: Christopher Chan Miller (cmiller@fas.harvard.edu)

Received: 13 January 2016 - Published in Atmos. Chem. Phys. Discuss.: 19 January 2016

Revised: 25 March 2016 - Accepted: 29 March 2016 - Published: 13 April 2016

\begin{abstract}
The Pearl River delta (PRD) is a densely populated hub of industrial activity located in southern China. OMI (Ozone Monitoring Instrument) satellite observations reveal a large hotspot of glyoxal (CHOCHO) over the PRD that is almost twice as large as any other in Asia. Formaldehyde ( $\mathrm{HCHO}$ ) and $\mathrm{NO}_{2}$ observed by OMI are also high in the PRD but no more than in other urban/industrial areas of China. The CHOCHO hotspot over the PRD can be explained by industrial paint and solvent emissions of aromatic volatile organic compounds (VOCs), with toluene being a dominant contributor. By contrast, $\mathrm{HCHO}$ in the PRD originates mostly from VOCs emitted by combustion (principally vehicles). By applying a plume transport model to wind-segregated OMI data, we show that the $\mathrm{CHOCHO}$ and $\mathrm{HCHO}$ enhancements over the PRD observed by OMI are consistent with current VOC emission inventories. Prior work using $\mathrm{CHOCHO}$ retrievals from the SCIAMACHY satellite instrument suggested that emission inventories for aromatic VOCs in the PRD were too low by a factor of 10-20; we attribute this result in part to bias in the SCIAMACHY data and in part to underestimated $\mathrm{CHOCHO}$ yields from oxidation of aromatics. Our work points to the importance of better understanding $\mathrm{CHOCHO}$ yields from the oxidation of aromatics in order to interpret space-based $\mathrm{CHOCHO}$ observations in polluted environments.
\end{abstract}

\section{Introduction}

The Pearl River delta (PRD) is a metropolis of nine cities on the southern coast of China with 57 million people as of 2013. Rapid economic growth over the past 3 decades has created a serious air quality problem within the region, with ozone $\left(\mathrm{O}_{3}\right)$ and particulate matter $(\mathrm{PM})$ air quality standards frequently violated. Volatile organic compounds (VOCs) are important $\mathrm{O}_{3}$ and $\mathrm{PM}$ precursors. Our recent retrieval of atmospheric glyoxal (CHOCHO) from the OMI (Ozone Monitoring Instrument) satellite instrument, including a number of corrections to previous retrievals, finds the $\mathrm{CHOCHO}$ column concentrations over the PRD to be the highest in the world (Chan Miller et al., 2014). Here we use the OMI satellite data for $\mathrm{CHOCHO}$ and formaldehyde (HCHO) in the PRD to evaluate VOC emission inventories used by atmospheric models and the related VOC chemistry.

The PRD has undergone rapid industrialization since 1980, when a series of economic reforms reduced restrictions on foreign investment. The PRD is now referred to as the "World Factory", producing $25 \%$ of China's exports (Guangdong Statistical Bureau, 2010). Major industries include printing, oil refining, chemical production, automobile assembly, and electronics manufacturing (Zhong et al., 2013).

This industrialization has led to worsening air quality throughout the region. Surface $\mathrm{O}_{3}$ and PM are routinely in excess of Chinese national ambient air quality standards (Liu et al., 2013). Ozone production in the PRD is predominantly VOC-limited (Zhang et al., 2007, 2008; Wang et al., 2010; 
Shao et al., 2009; Xue et al., 2014), and the aromatic species toluene and xylene play a dominant role (Xue et al., 2014). Aromatics have also been identified as an important regional source of secondary organic aerosol via reactive uptake of their oxidation products ( $\mathrm{Li}$ et al., 2013), including glyoxal (Fu et al., 2008).

$\mathrm{CHOCHO}$ is a high-yield product of aromatic oxidation (Nishino et al., 2010). Previous analyses of CHOCHO satellite observations over China have suggested that inventories of aromatic emissions are too low. Stavrakou et al. (2009) used 2005 observations of $\mathrm{CHOCHO}$ and $\mathrm{HCHO}$ from the SCIAMACHY satellite instrument and found the global RETRO VOC inventory (Schultz et al., 2007) to be too low in the PRD by over a factor of 2. Liu et al. (2012) used 2007 SCIAMACHY CHOCHO observations and found the INTEX-B East Asian inventory (Zhang et al., 2009) to be too low in the PRD by a factor of 10-20.

Our OMI CHOCHO retrieval is systematically lower than the older SCIAMACHY data, with very different patterns, as a result of improved background corrections and removal of $\mathrm{NO}_{2}$ interferences (Chan Miller et al., 2014). An independent OMI CHOCHO retrieval by Alvarado et al. (2014) is also systematically lower than SCIAMACHY. This calls for revisiting the interpretation of $\mathrm{CHOCHO}$ data from space. Focus on the PRD not only targets a hotspot in the OMI data, but enables comparison to a highly detailed local VOC inventory for the region (Zheng et al., 2009a, b).

\section{Data and methods}

The OMI was launched onboard the NASA Aura satellite in July 2004 (Levelt et al., 2006). Aura is in sun-synchronous orbit with an equatorial crossing time of 13:38 LT (local time). OMI measures backscattered solar radiation at a nadir spatial resolution of $13 \mathrm{~km} \times 24 \mathrm{~km}$ and achieves daily global coverage by cross-track imaging. Spectral fitting yields slant columns of $\mathrm{CHOCHO}, \mathrm{HCHO}$ and $\mathrm{NO}_{2}$ along the optical path. These are converted to vertical columns using air mass factors (AMFs) that combine scattering weights and vertical concentration profiles (González Abad et al., 2015). We use CHOCHO data from Chan Miller et al. (2014), and HCHO and $\mathrm{NO}_{2}$ data from the OMI Version 3 product release (González Abad et al., 2015; Bucsela et al., 2013). Vertical profiles for the AMF computation are from the GEOS-Chem chemical transport model (v9-01-3; http://geos-chem.org). GEOS-Chem was originally described by Bey et al. (2001) and the glyoxal simulation was first introduced by $\mathrm{Fu}$ et al. (2008). The chemical mechanism in v9-01-3 is described in Mao et al. (2013).

Observations are averaged on a $0.25^{\circ} \times 0.3125^{\circ}$ grid using an area-weighted tessellation algorithm (Spurr, 2004). We exclude observations from the first and last cross-track positions, those that fail the retrieval algorithm statistical quality checks, and those impacted by the row anomaly (http://www.knmi.nl/omi/research/product/ rowanomaly-background.php). Validation with aircraft data indicates that the OMI $\mathrm{HCHO}$ and $\mathrm{NO}_{2}$ retrievals are accurate within 20 and $30 \%$, respectively (Lamsal et al., 2014; Zhu et al., 2016). CHOCHO/HCHO column ratios from OMI are consistent with aircraft observations (Kaiser et al., 2015), whereas previous SCIAMACHY retrievals showed large discrepancies (DiGangi et al., 2012).

We relate the $\mathrm{CHOCHO}$ and $\mathrm{HCHO}$ satellite observations over the PRD to VOC emissions using a 1-D advectivereactive plume model (Beirle et al., 2011; Valin et al., 2013), assuming a constant wind $u$, and treating the PRD as a Gaussian-distributed source $(N(x ; \sigma))$ orthogonal to the wind with total emission rate $E_{i}\left(\right.$ e.g., $\left.\mathrm{mol} \mathrm{s}^{-1}\right)$. Let $l_{i}$ represent the vertical column density of VOC species $i$ integrated in the horizontal orthogonally to the wind (molecules $\mathrm{cm}^{-1}$ ). The continuity equation is written as

$$
\begin{aligned}
& \frac{\partial l_{i}(x, t)}{\partial t}+u \frac{\partial l_{i}(x, t)}{\partial x} \\
& =E_{i}(t) N(x ; \sigma)-k_{i}[\mathrm{OH}](t) l_{i}(x, t) .
\end{aligned}
$$

Here $k_{i}$ is the rate constant of the reaction of VOC $i$ with the hydroxyl radical $\mathrm{OH}$ (the main sink for the VOCs of interest). The local diurnally varying concentration of $\mathrm{OH}$ is calculated from GEOS-Chem and peaks at $1.5 \times 10^{7}$ molecules $\mathrm{cm}^{-3}$ at local noon, close to observed values in the PRD (Hofzumahaus et al., 2009). $E_{i}$ varies diurnally using source scaling factors from GEOS-Chem (van Donkelaar et al., 2008). We use the $\mathrm{NO}_{2}$ plume as a proxy to derive the along-trajectory width of the VOC source region $(\sigma)$, using the exponential decay model from Beirle et al. (2011). The derived halfmaximum width $(\sim 85 \mathrm{~km})$ is reasonable given the observed extent of PRD urban land cover from MODIS.

$\mathrm{CHOCHO}$ is treated as a product of VOC oxidation with yield $\alpha_{i}$ from $\operatorname{VOC} i$, and is lost by reaction with $\mathrm{OH}$ and photolysis (rate constants $k_{g}$ and $J_{g}$, respectively). The CHOCHO vertical column density integrated in the horizontal orthogonal to the wind $(g(x, t))$ is then given by

$$
\begin{aligned}
& \frac{\partial g(x, t)}{\partial t}+u \frac{\partial g(x, t)}{\partial x} \\
& =\sum_{i} \alpha_{i} k_{i}[\mathrm{OH}](t) l_{i}(x, t)-\left\{k_{g}[\mathrm{OH}](t)+J_{g}(t)\right\} g(x, t) .
\end{aligned}
$$

A similar equation holds for HCHO. $J_{g}$ is calculated using the Fast-JX radiative transfer model (Wild et al., 2000; Neu et al., 2007). The yields $\left(\alpha_{i}\right)$ are calculated for a 1-day VOC aging time using the box model simulation of Palmer et al. (2006) with the MCMv3.2 chemical mechanism (Jenkin et al., 1997, 2003; Bloss et al., 2005), and assuming a high$\mathrm{NO}_{x}$ regime where organic peroxy radical products of VOC oxidation react mainly with NO.

We apply the plume model to VOC emissions from five different inventories - RETRO (Schultz et al., 2007), MACCity (Granier et al., 2011), 


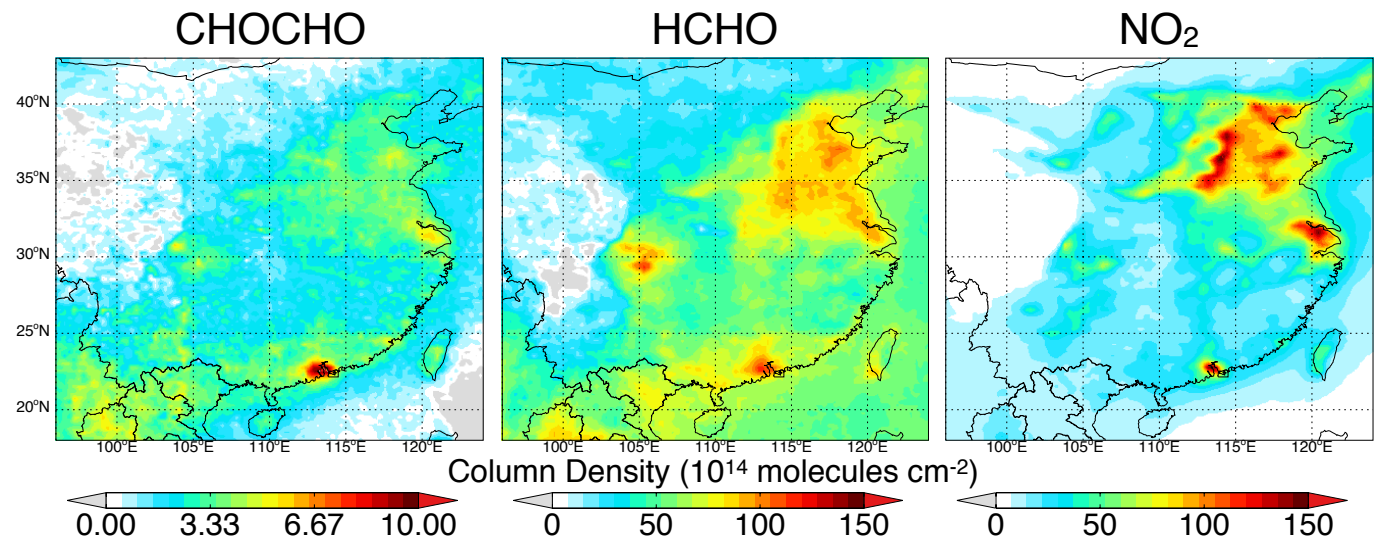

Figure 1. Annual mean vertical column densities of $\mathrm{NO}_{2}, \mathrm{HCHO}$, and $\mathrm{CHOCHO}$ for 2006-2007. Values are OMI observations from Chan Miller et al. (2014) for CHOCHO, González Abad et al. (2015) for HCHO, and Bucsela et al. (2013) for $\mathrm{NO}_{2}$.
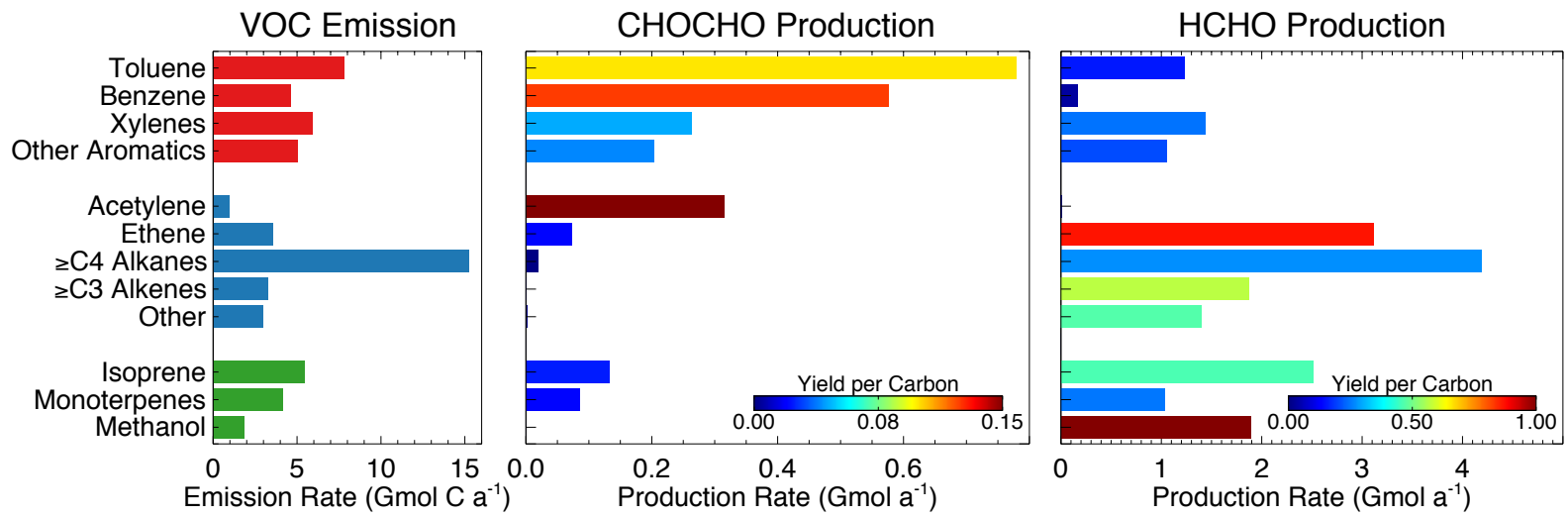

Figure 2. Yearly VOC emissions (2006) in the PRD $\left(21.5-24^{\circ} \mathrm{N}, 112-115.5^{\circ} \mathrm{E}\right)$ and corresponding yields and production rates of $\mathrm{CHOCHO}$ and $\mathrm{HCHO}$ over 1 day of aging. VOC emissions are from Zheng et al. (2009a). Yields are computed using the MCMv3.2 chemical mechanism (Jenkin et al., 1997, 2003).

REASv2 (Kurokawa et al., 2013), INTEX-B (Zhang et al., 2009), and the local PRD inventory from Zheng et al. (2009a).

\section{Results and discussion}

Figure 1 shows the mean 2006-2007 vertical columns of $\mathrm{CHOCHO}, \mathrm{HCHO}$, and tropospheric $\mathrm{NO}_{2}$ over China. OMI $\mathrm{CHOCHO}$ columns in the PRD $\left(23^{\circ} \mathrm{N}, 113^{\circ} \mathrm{E}\right)$ peak at $1.0 \times 10^{15}$ molecules $\mathrm{cm}^{-2}$, the highest in the world on an annual basis (Chan Miller et al., 2014). HCHO in the PRD is also high but comparable to values in the industrial Szechuan Basin to the northwest and in the densely populated East China Plain. $\mathrm{NO}_{2}$ is high but less than in the East China Plain. As pointed out previously by Liu et al. (2012) and Li et al. (2014), the unusually high $\mathrm{CHOCHO}$ concentrations over the PRD can be attributed to high emissions of aromatic VOCs.
The Zheng et al. (2009a) PRD emissions inventory includes detailed VOC speciation profiles of local sources (Liu et al., 2008a; Lai et al., 2009), resolving 91 individual VOCs, and adds biogenic VOC emissions from GloBEIS (Zheng et al., 2009c). The inventory does not contain primary $\mathrm{CHOCHO}$ emissions, and primary $\mathrm{HCHO}$ emissions are negligibly small.

Figure 2 shows the VOC emissions from Zheng et al. (2009a) and the corresponding $\mathrm{HCHO}$ and $\mathrm{CHOCHO}$ production rates. Aromatic VOCs have higher $\mathrm{CHOCHO}$ yields than other precursors, and their emissions are high enough to dominate $\mathrm{CHOCHO}$ production. Paints and solvents are the largest source of aromatics in the inventory, responsible for over $50 \%$ of benzene, toluene and xylene emissions. Atmospheric VOC observations in the PRD are consistent with that solvent/paint signature (Liu et al., 2008b; Barletta et al., 2008), in contrast to other Chinese cities, where VOC emissions are predominantly from combustion (Barletta et al., 2005). Acetylene emitted from combustion has a $64 \%$ ul- 

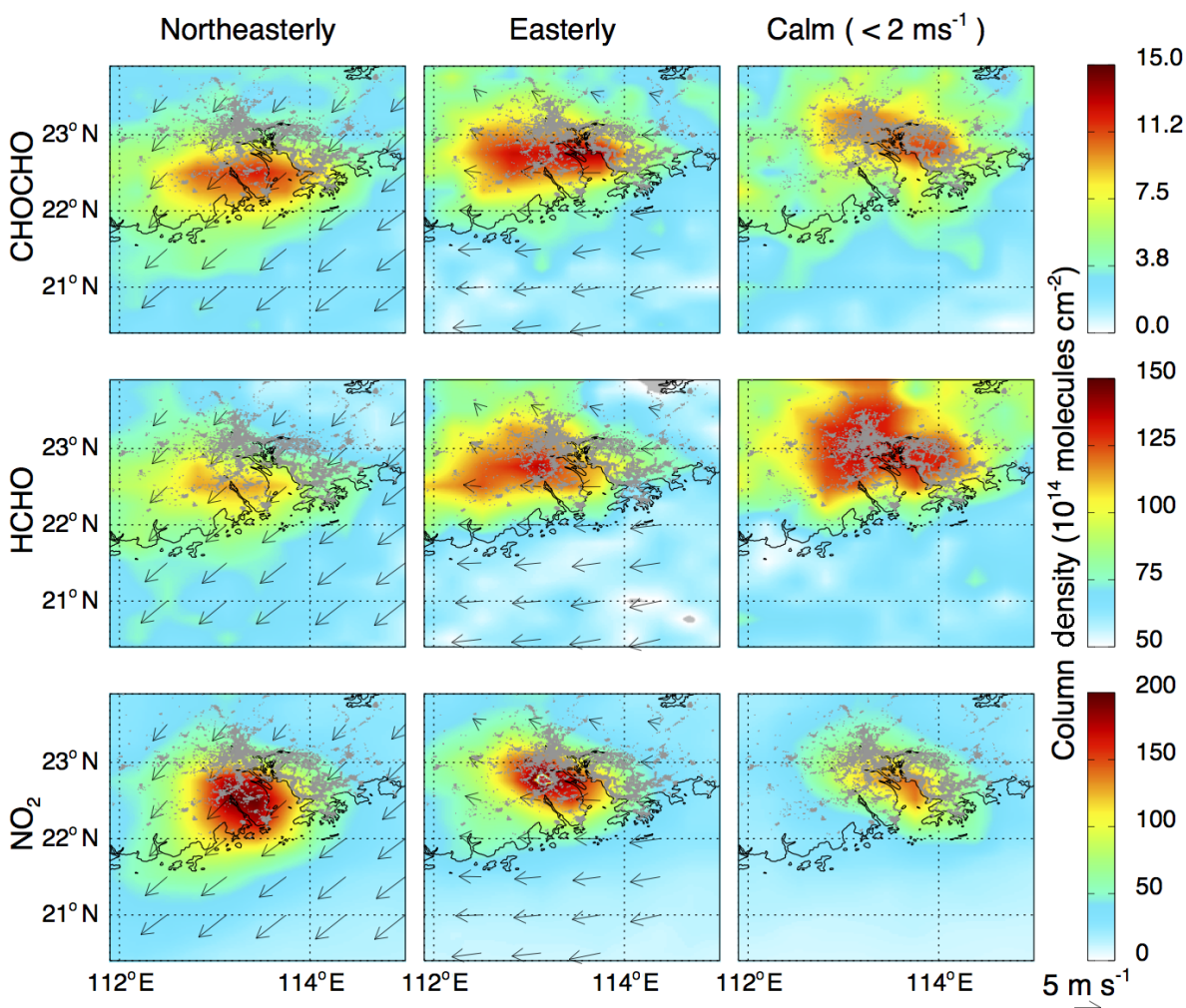

Figure 3. Mean OMI vertical column densities of $\mathrm{CHOCHO}, \mathrm{HCHO}$, and $\mathrm{NO}_{2}$ over the PRD for 2006 to 2007, segregated by wind direction. Wind vectors at $60 \mathrm{~m}$ altitude are from the NASA GEOS-5 assimilated meteorology product. The distribution of urban land cover from the MODIS type 5 land cover product is shown in grey.

timate yield of CHOCHO (Fu et al., 2008), but its lifetime is too long (about 10 days) to make a major contribution to the local CHOCHO budget.

$\mathrm{HCHO}$ is produced with a more consistent yield from different VOCs, as shown in Fig. 2. VOCs emitted by vehicles including alkenes and $\geq \mathrm{C}_{4}$ alkanes play a dominant role in $\mathrm{HCHO}$ production, with biogenic isoprene making an additional seasonal contribution. This explains why OMI HCHO columns in the PRD are comparable to other Chinese urban areas (Fig. 1).

Figure 3 shows mean 2006-2007 OMI columns over the PRD segregated by northeasterly, easterly, and calm $\left(<2 \mathrm{~m} \mathrm{~s}^{-1}\right)$ wind conditions. The segregation is based on GEOS-5 surface wind data at Shenzhen $\left(23.5^{\circ} \mathrm{N}, 114^{\circ} \mathrm{E}\right)$. The shape of the urban plume is consistent with wind direction. Ninety percent of northeasterly conditions are in fall and winter. Fifty percent of calm conditions are in summer, and easterly conditions are evenly spread over the seasons. These seasonal dependences explain the higher $\mathrm{HCHO}$ columns under calm conditions, as biogenic VOCs make a larger contribution in summer (Zheng et al., 2010). On the other hand, $\mathrm{NO}_{2}$ is lower because of faster photochemical loss. CHO$\mathrm{CHO}$ shows much less variability between wind sectors, consistent with a dominant anthropogenic source and with photochemistry driving both production and loss.
We select observations from the northeasterly sector for application of the advective-reactive plume model to evaluate emission inventories. Wind under these conditions is relatively steady, with low diurnal variability, and the urban plume is transported over flat terrain. The prevailing fall/winter conditions minimize the influence of biogenic VOCs.

Figure 4 shows cross-wind integrals of $\mathrm{CHOCHO}$ and $\mathrm{HCHO}$ vertical column densities as a function of transport time calculated using the Zheng et al. (2009a) local inventory along the mean flow trajectories, and initialized upwind of the PRD. A regional background has been subtracted prior to integration using observations in a sector upwind of the plume source $\left(114-116^{\circ} \mathrm{E}, 22-23^{\circ} \mathrm{N}\right)$. We ascribe a $20 \%$ relative error to the observations from systematic AMF uncertainties (Vrekoussis et al., 2010) and a spatially uniform error from uncertainty in the background column value (Zhu et al., 2014).

Also shown in Fig. 4 are the results from the advectivereactive plume model using the Zheng et al. (2009a) PRD emission inventory for individual VOCs, with MCMv3.2 yields for $\mathrm{HCHO}$ and $\mathrm{CHOCHO}$ (Fig. 2). The model does not include biogenic emissions (isoprene, monoterpenes, and methanol), which are relatively weak in fall/winter and would be included in the regional background. The anthro- 

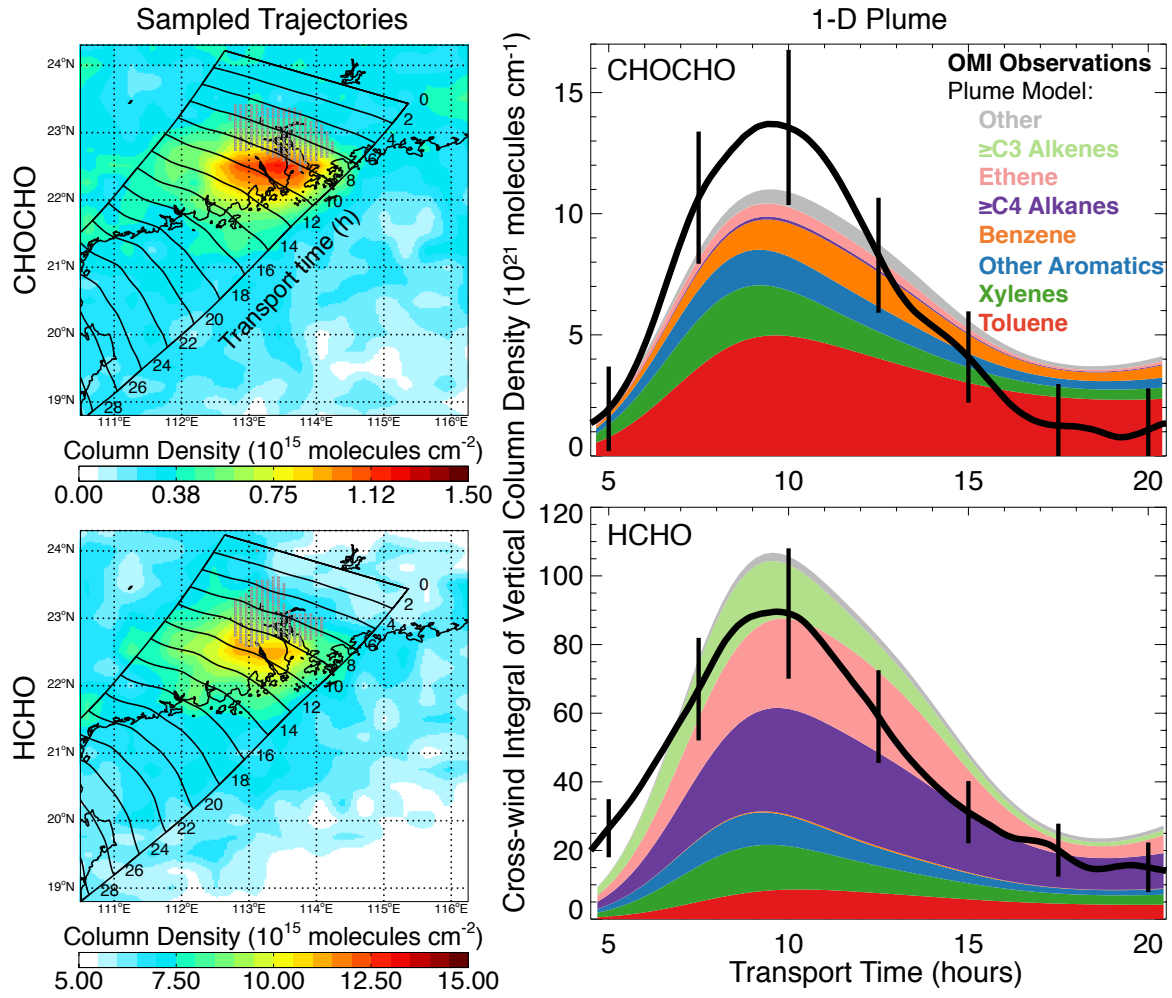

Figure 4. Mean CHOCHO and HCHO PRD plumes under northeasterly flow conditions. Left: vertical column densities, overlaid with surface air $(60 \mathrm{~m})$ trajectories for the mean wind field of Fig. 3. The trajectories are initialized upwind of the PRD $(t=0)$, and transport times in hours along the trajectories are indicated. The grey hatched area indicates the location of maximum emissions as diagnosed by the peak concentrations for the calm wind conditions in Fig. $3\left(8 \times 10^{14}\right.$ and $1.25 \times 10^{16}$ molecules cm ${ }^{-2}$ for CHOCHO and HCHO, respectively). Right: $\mathrm{CHOCHO}$ and HCHO cross-wind integrals of vertical column density. The OMI observations are line integrals across the trajectories in the left panels, and vertical bars are retrieval uncertainties. The stacked contours are results from the 1-D plume model showing the contributions from individual VOCs as given by the Zheng et al. (2009a) PRD inventory, combined with the CHOCHO and HCHO yields of Fig. 2. VOC emissions in the plume model for CHOCHO and $\mathrm{HCHO}$ are centered at transport time $t=6.5$ and $t=7.0 \mathrm{~h}$, respectively, based on the plume location during calm wind conditions.

pogenic emissions are released at $t=6.5 \mathrm{~h}$ for $\mathrm{CHOCHO}$ and $t=7 \mathrm{~h}$ for $\mathrm{HCHO}$, based on the location of the observed maximum column of each species during calm conditions (Fig. 3).

Figure 4 shows that the model can generally replicate the observed concentrations (line densities) of $\mathrm{CHOCHO}$ and $\mathrm{HCHO}$ as a function of transport time. We do not expect the model to perfectly replicate the shape of the plume, due to its simplistic treatment of transport, spatiotemporal allocation of emissions, and chemistry. Comparison of the integrated plume totals of the model and OMI is more robust. Specification of $\mathrm{OH}$ concentrations and photolysis rates is a source of uncertainty in the modeled plume total. We estimate a $30 \%$ uncertainty in $\mathrm{OH}$ concentrations, and a $20 \%$ uncertainty for photolysis rates, with the latter driven by aerosol scattering (Martin et al., 2003). Integrating the plume model results between $t=5$ and $t=20 \mathrm{~h}$ in Fig. 4, we find good agreement with OMI for both $\mathrm{CHOCHO}(370 \pm 50 \mathrm{kmol}$ modeled vs. $350 \pm 90 \mathrm{kmol} \mathrm{OMI})$ and $\mathrm{HCHO}(3.2 \pm 0.6 \mathrm{Mmol}$ modeled vs. $2.6 \pm 0.7 \mathrm{Mmol} \mathrm{OMI}$ ), and conclude that the PRD inventory of Zheng et al. (2009a) is consistent with observations.

We repeated the same plume model calculation with the INTEX-B, REASv2, RETRO, and MACCity emission inventories for the PRD. All inventories are for 2006 except RETRO (2000). Figure 5 shows the emissions from each inventory, together with integrated $\mathrm{CHOCHO}$ and $\mathrm{HCHO}$ plume enhancements in the PRD integrating the OMI observations and plume model results in Fig. 4 between $t=5$ and $t=20 \mathrm{~h}$. With the exception of RETRO, all inventories have similar total VOC emissions on a per $\mathrm{C}$ basis, though they differ in speciation, and they reproduce the observed $\mathrm{CHOCHO}$ and $\mathrm{HCHO}$ plumes within $40 \%$ for $\mathrm{CHOCHO}$ and $55 \%$ for $\mathrm{HCHO}$.

The good agreement between VOC emission inventories and satellite observations of $\mathrm{CHOCHO}$ and $\mathrm{HCHO}$ is in sharp disagreement with Liu et al. (2012), who inferred a 10-20-fold underestimation of PRD aromatic emissions in the INTEX-B inventory using SCIAMACHY CHOCHO ob- 


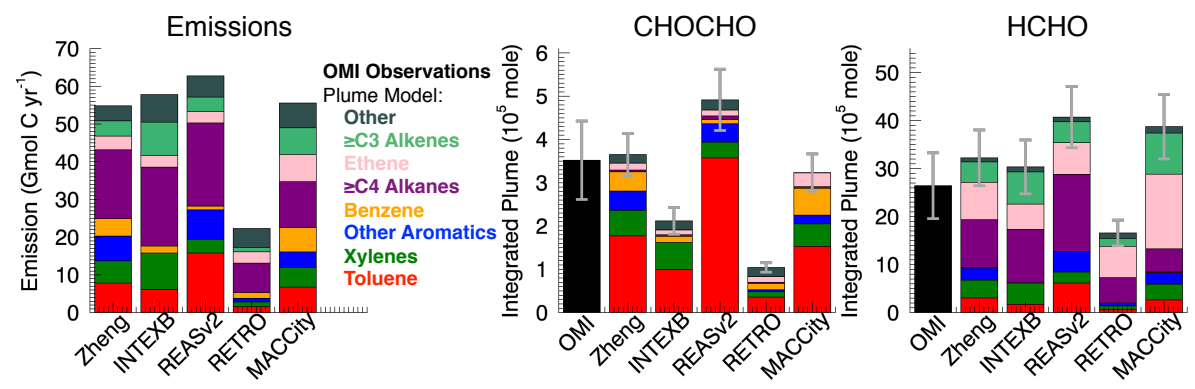

Figure 5. VOC emissions in the PRD from five different inventories (see text), and corresponding plume amounts of $\mathrm{CHOCHO}$ and $\mathrm{HCHO}$ as computed from the plume model discussed in the text and integrated from $t=5$ to $t=20 \mathrm{~h}$ on the trajectory time grid shown in Fig. 4 . Model uncertainty bars are from uncertainties in $\mathrm{OH}$ concentrations and photolysis rates (see text). OMI observations integrated on the same trajectory grid are also shown.

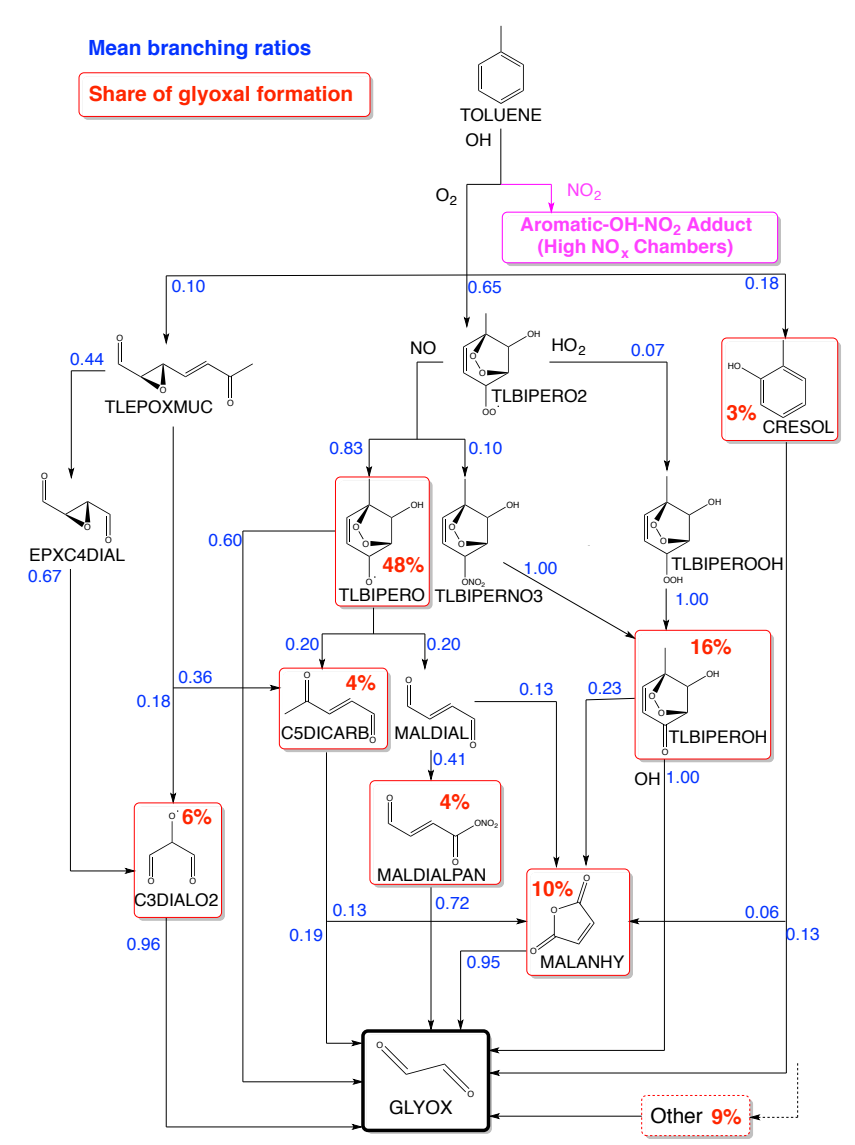

Figure 6. Pathways to glyoxal formation from toluene oxidation by $\mathrm{OH}$ in $\mathrm{MCMv3.2}$. Only species relevant to $\mathrm{CHOCHO}$ formation are shown, and are labeled by their MCMv3.2 name. Branching ratios (blue) and the share of glyoxal formation from each boxed species (red) are from the $24 \mathrm{~h}$ box model simulation described in the text. The high $\mathrm{NO}_{2}$ pathway (not in MCMv3.2 but relevant in chamber studies) is indicated in pink. servations. The same inventory in our plume model underestimates the OMI CHOCHO concentration by only a factor of 2. Increasing aromatic VOC emissions by a factor of 10 would also overestimate $\mathrm{HCHO}$ by more than a factor of 2 .

Annually averaged SCIAMACHY CHOCHO columns are $\sim 60 \%$ higher than OMI in the PRD, but this is not enough to explain the difference. Different aromatic CHOCHO yields likely play a larger role. Molar yields of $\mathrm{CHOCHO}$ in Liu et al. (2012) were $25 \%$ for benzene, $16 \%$ for toluene, and $16 \%$ for xylenes, based on a literature average of chamber experiments compiled by Fu et al. (2008). By contrast, the MCMv3.2 molar yields used here are $75 \%$ for benzene, $70 \%$ for toluene, and $36 \%$ for xylenes.

Figure 6 shows the pathways to $\mathrm{CHOCHO}$ formation from toluene in MCMv3.2. Approximately half of $\mathrm{CHOCHO}$ formation in MCMv3.2 is produced as a first-generation product via a bicyclic intermediate (TLBIPERO). The rest of CHO$\mathrm{CHO}$ production involves intermediate products, implying delays and additional uncertainties.

Studies reporting $\mathrm{CHOCHO}$ yields at the lower end of the range reported in Fu et al. (2008) were conducted under very high $\mathrm{NO}_{x}$ conditions, resulting in $\mathrm{OH}$-adduct reactions (pink pathway, Fig. 6) that would suppress CHOCHO formation (Nishino et al., 2010). The highest yield of $39.0 \pm 10.2 \%$ measured by Volkamer et al. (2001) was performed under $\mathrm{NO}_{x}$ levels closer to ambient conditions; however, it was later revised to $30.6 \pm 6.0 \%$ after $\mathrm{CHOCHO}$ measurements from the experiment were revised downward based on more accurate $\mathrm{CHOCHO}$ absorption cross sections (Volkamer et al., 2005). Nishino et al. (2010) corrected for $\mathrm{NO}_{2}$ reactions in their kinetics analysis to determine a yield of $26.0 \pm 2.2 \%$, in close agreement with Volkamer et al. (2001). In both studies, CHOCHO production was solely from first-generation production. This is very consistent with the $32 \%$ first-generation CHOCHO yield from MCMv3.2 via TLBIPERO (Fig. 6). Thus the higher yield of $\mathrm{CHOCHO}$ from toluene in the MCMv3.2 mechanism relative to the $\mathrm{Fu}$ et al. (2008) compilation is due to the accounting of latergeneration production. 
Bloss et al. (2005) experimentally observed CHOCHO production from butenedial (MALDIAL), confirming the existence of later-generation $\mathrm{CHOCHO}$ production from toluene. Other later-generation $\mathrm{CHOCHO}$ formation pathways in MCMv3.2 still need to be experimentally confirmed. However, the combined data on $\mathrm{CHOCHO}$ and $\mathrm{HCHO}$ from the satellite observations do provide additional constraints. If the $\mathrm{CHOCHO}$ yield from aromatics were much lower than MCMv3.2, then aromatic emissions would need to be increased in a way that would be inconsistent with the $\mathrm{HCHO}$ data.

In conclusion, the $\mathrm{CHOCHO}$ hotspot over the Pearl River delta seen by the OMI satellite instrument can be explained by a very large industrial source of aromatic VOCs, consistent with current emission inventories used in atmospheric models. There has been little confidence in the past in interpreting $\mathrm{CHOCHO}$ data from space, in part because of inconsistency with surface observations (DiGangi et al., 2012). This issue seems to be resolved with the OMI observations (Chan Miller et al., 2014), and we find CHOCHO to be an excellent tracer of aromatic VOC emissions where these are high. Further work will need to examine other sources of $\mathrm{CHOCHO}$ relevant to interpreting satellite observations, in particular biogenic isoprene. The multi-generation CHO$\mathrm{CHO}$ yields from the atmospheric oxidation of aromatic VOCs also need to be better established.

Acknowledgements. This work was supported by the NASA Aura Science Team.

Edited by: B. N. Duncan

\section{References}

Alvarado, L. M. A., Richter, A., Vrekoussis, M., Wittrock, F., Hilboll, A., Schreier, S. F., and Burrows, J. P.: An improved glyoxal retrieval from OMI measurements, Atmos. Meas. Tech., 7, 4133-4150, doi:10.5194/amt-7-4133-2014, 2014.

Barletta, B., Meinardi, S., Sherwood Rowland, F., Chan, C.-Y., Wang, X., Zou, S., Yin Chan, L., and Blake, D. R.: Volatile organic compounds in 43 Chinese cities, Atmos. Environ., 39, 5979-5990, 2005.

Barletta, B., Meinardi, S., Simpson, I. J., Zou, S., Rowland, F. S., and Blake, D. R.: Ambient mixing ratios of nonmethane hydrocarbons (NMHCs) in two major urban centers of the Pearl River Delta (PRD) region: Guangzhou and Dongguan, Atmos. Environ., 42, 4393-4408, doi:10.1016/j.atmosenv.2008.01.028, 2008.

Beirle, S., Boersma, K. F., Platt, U., Lawrence, M. G., and Wagner, T.: Megacity Emissions and Lifetimes of Nitrogen Oxides Probed from Space, Science, 333, 1737-1739, doi:10.1126/science.1207824, 2011.

Bey, I., Jacob, D. J., Yantosca, R. M., Logan, J. A., Field, B. D., Fiore, A. M., Li, Q., Liu, H. Y., Mickley, L. J., and Schultz, M. G.: Global modeling of tropospheric chemistry with assimilated meteorology: Model description and evaluation, J. Geophys. Res.-Atmos., 106, 23073-23095, doi:10.1029/2001JD000807, 2001.

Bloss, C., Wagner, V., Jenkin, M. E., Volkamer, R., Bloss, W. J., Lee, J. D., Heard, D. E., Wirtz, K., Martin-Reviejo, M., Rea, G., Wenger, J. C., and Pilling, M. J.: Development of a detailed chemical mechanism (MCMv3.1) for the atmospheric oxidation of aromatic hydrocarbons, Atmos. Chem. Phys., 5, 641-664, doi:10.5194/acp-5-641-2005, 2005.

Bucsela, E. J., Krotkov, N. A., Celarier, E. A., Lamsal, L. N., Swartz, W. H., Bhartia, P. K., Boersma, K. F., Veefkind, J. P., Gleason, J. F., and Pickering, K. E.: A new stratospheric and tropospheric $\mathrm{NO}_{2}$ retrieval algorithm for nadir-viewing satellite instruments: applications to OMI, Atmos. Meas. Tech., 6, 26072626, doi:10.5194/amt-6-2607-2013, 2013.

Chan Miller, C., Gonzalez Abad, G., Wang, H., Liu, X., Kurosu, T., Jacob, D. J., and Chance, K.: Glyoxal retrieval from the Ozone Monitoring Instrument, Atmos. Meas. Tech., 7, 38913907, doi:10.5194/amt-7-3891-2014, 2014.

DiGangi, J. P., Henry, S. B., Kammrath, A., Boyle, E. S., Kaser, L., Schnitzhofer, R., Graus, M., Turnipseed, A., Park, J.-H., Weber, R. J., Hornbrook, R. S., Cantrell, C. A., Maudlin III, R. L., Kim, S., Nakashima, Y., Wolfe, G. M., Kajii, Y., Apel, E. C., Goldstein, A. H., Guenther, A., Karl, T., Hansel, A., and Keutsch, F. N.: Observations of glyoxal and formaldehyde as metrics for the anthropogenic impact on rural photochemistry, Atmos. Chem. Phys., 12, 9529-9543, doi:10.5194/acp-12-9529-2012, 2012.

Fu, T.-M., Jacob, D. J., Wittrock, F., Burrows, J. P., Vrekoussis, M., and Henze, D. K.: Global budgets of atmospheric glyoxal and methylglyoxal, and implications for formation of secondary organic aerosols, J. Geophys. Res., 113, D15303, doi:10.1029/2007JD009505, 2008.

González Abad, G., Liu, X., Chance, K., Wang, H., Kurosu, T. P., and Suleiman, R.: Updated Smithsonian Astrophysical Observatory Ozone Monitoring Instrument (SAO OMI) formaldehyde retrieval, Atmos. Meas. Tech., 8, 19-32, doi:10.5194/amt-8-192015, 2015.

Granier, C., Bessagnet, B., Bond, T., D’Angiola, A., Denier van der Gon, H., Frost, G., Heil, A., Kaiser, J., Kinne, S., Klimont, Z., Kloster, S., Lamarque, J.-F., Liousse, C., Masui, T., Meleux, F., Mieville, A., Ohara, T., Raut, J.-C., Riahi, K., Schultz, M., Smith, S., Thompson, A., van Aardenne, J., van der Werf, G., and van Vuuren, D.: Evolution of anthropogenic and biomass burning emissions of air pollutants at global and regional scales during the 1980-2010 period, Climate Change, 109, 163-190, doi:10.1007/s10584-011-0154-1, 2011.

Guangdong Statistical Bureau \& Guangdong Survey Office of National Bureau of Statistics: Guangdong Statistical Yearbook, China Statistics Press, 2010.

Hofzumahaus, A., Rohrer, F., Lu, K., Bohn, B., Brauers, T., Chang, C.-C., Fuchs, H., Holland, F., Kita, K., Kondo, Y., Li, X., Lou, S., Shao, M., Zeng, L., Wahner, A., and Zhang, Y.: Amplified Trace Gas Removal in the Troposphere, Science, 324, 17021704, doi:10.1126/science.1164566, 2009.

Jenkin, M. E., Saunders, S. M., and Pilling, M. J.: The tropospheric degradation of volatile organic compounds: a protocol for mechanism development, Atmos. Environ., 31, 81-104, doi:10.1016/S1352-2310(96)00105-7, 1997.

Jenkin, M. E., Saunders, S. M., Wagner, V., and Pilling, M. J.: Protocol for the development of the Master Chemical Mecha- 
nism, MCM v3 (Part B): tropospheric degradation of aromatic volatile organic compounds, Atmos. Chem. Phys., 3, 181-193, doi:10.5194/acp-3-181-2003, 2003.

Kaiser, J., Wolfe, G. M., Min, K. E., Brown, S. S., Miller, C. C., Jacob, D. J., deGouw, J. A., Graus, M., Hanisco, T. F., Holloway, J., Peischl, J., Pollack, I. B., Ryerson, T. B., Warneke, C., Washenfelder, R. A., and Keutsch, F. N.: Reassessing the ratio of glyoxal to formaldehyde as an indicator of hydrocarbon precursor speciation, Atmos. Chem. Phys., 15, 7571-7583, doi:10.5194/acp-157571-2015, 2015.

Kurokawa, J., Ohara, T., Morikawa, T., Hanayama, S., JanssensMaenhout, G., Fukui, T., Kawashima, K., and Akimoto, H.: Emissions of air pollutants and greenhouse gases over Asian regions during 2000-2008: Regional Emission inventory in ASia (REAS) version 2, Atmos. Chem. Phys., 13, 11019-11058, doi:10.5194/acp-13-11019-2013, 2013.

Lai, C.-H., Chang, C.-C., Wang, C.-H., Shao, M., Zhang, Y., and Wang, J.-L.: Emissions of liquefied petroleum gas (LPG) from motor vehicles, Atmos. Environ., 43, 1456-1463, doi:10.1016/j.atmosenv.2008.11.045, 2009.

Lamsal, L. N., Krotkov, N. A., Celarier, E. A., Swartz, W. H., Pickering, K. E., Bucsela, E. J., Gleason, J. F., Martin, R. V., Philip, S., Irie, H., Cede, A., Herman, J., Weinheimer, A., Szykman, J. J., and Knepp, T. N.: Evaluation of OMI operational standard $\mathrm{NO}_{2}$ column retrievals using in situ and surface-based $\mathrm{NO}_{2}$ observations, Atmos. Chem. Phys., 14, 11587-11609, doi:10.5194/acp14-11587-2014, 2014.

Levelt, P., van den Oord, G., Dobber, M., Malkki, A., Visser, H., de Vries, J., Stammes, P., Lundell, J., and Saari, H.: The ozone monitoring instrument, IEEE T. Geosci. Remote., 44, 10931101, doi:10.1109/TGRS.2006.872333, 2006.

Li, N., Fu, T.-M., Cao, J., Lee, S., Huang, X.-F., He, L.-Y., Ho, K.-F., Fu, J. S., and Lam, Y.-F.: Sources of secondary organic aerosols in the Pearl River Delta region in fall: Contributions from the aqueous reactive uptake of dicarbonyls, Atmos. Environ., 76, 200-207, doi:10.1016/j.atmosenv.2012.12.005, 2013.

Li, X., Rohrer, F., Brauers, T., Hofzumahaus, A., Lu, K., Shao, M., Zhang, Y. H., and Wahner, A.: Modeling of HCHO and CHO$\mathrm{CHO}$ at a semi-rural site in southern China during the PRIDEPRD2006 campaign, Atmos. Chem. Phys., 14, 12291-12305, doi:10.5194/acp-14-12291-2014, 2014.

Liu, H., Wang, X. M., Pang, J. M., and He, K. B.: Feasibility and difficulties of China's new air quality standard compliance: PRD case of $\mathrm{PM}_{2.5}$ and ozone from 2010 to 2025, Atmos. Chem. Phys., 13, 12013-12027, doi:10.5194/acp-13-12013-2013, 2013.

Liu, Y., Shao, M., Fu, L., Lu, S., Zeng, L., and Tang, D.: Source profiles of volatile organic compounds (VOCs) measured in China: Part I, Atmos. Environ., 42, 6247-6260, doi:10.1016/j.atmosenv.2008.01.070, 2008a.

Liu, Y., Shao, M., Lu, S., Chang, C.-C., Wang, J.-L., and Fu, L.: Source apportionment of ambient volatile organic compounds in the Pearl River Delta, China: Part II, Atmos. Environ., 42, 62616274, doi:10.1016/j.atmosenv.2008.02.027, 2008b.

Liu, Z., Wang, Y., Vrekoussis, M., Richter, A., Wittrock, F., Burrows, J. P., Shao, M., Chang, C.-C., Liu, S.-C., Wang, H., and Chen, C.: Exploring the missing source of glyoxal (CHOCHO) over China, Geophys. Res. Lett., 39, L10812, doi:10.1029/2012GL051645, 2012.
Mao, J., Paulot, F., Jacob, D. J., Cohen, R. C., Crounse, J. D., Wennberg, P. O., Keller, C. A., Hudman, R. C., Barkley, M. P., and Horowitz, L. W.: Ozone and organic nitrates over the eastern United States: Sensitivity to isoprene chemistry, J. Geophys. Res.-Atmos., 118, 11256-11268, doi:10.1002/jgrd.50817, 2013.

Martin, R. V., Jacob, D. J., Yantosca, R. M., Chin, M., and Ginoux, P.: Global and regional decreases in tropospheric oxidants from photochemical effects of aerosols, J. Geophys. Res.-Atmos., 108, 4097, doi:10.1029/2002JD002622, 2003.

Neu, J. L., Prather, M. J., and Penner, J. E.: Global atmospheric chemistry: Integrating over fractional cloud cover, J. Geophys. Res.-Atmos., 112, D11306, doi:10.1029/2006JD008007, 2007.

Nishino, N., Arey, J., and Atkinson, R.: Formation Yields of Glyoxal and Methylglyoxal from the Gas-Phase OH RadicalInitiated Reactions of Toluene, Xylenes, and Trimethylbenzenes as a Function of $\mathrm{NO}_{2}$ Concentration, J. Phys. Chem. A, 114, 10140-10147, doi:10.1021/jp105112h, 2010.

Palmer, P. I., Abbot, D. S., Fu, T.-M., Jacob, D. J., Chance, K., Kurosu, T. P., Guenther, A., Wiedinmyer, C., Stanton, J. C., Pilling, M. J., Pressley, S. N., Lamb, B., and Sumner, A. L.: Quantifying the seasonal and interannual variability of North American isoprene emissions using satellite observations of the formaldehyde column, J. Geophys. Res.-Atmos., 111, D12315, doi:10.1029/2005JD006689, 2006.

Schultz, M. G., Backman, L., Balkanski, Y., Bjoerndalsaeter, S., Brand, R., Burrows, J. P., Dalsoeren, S., de Vasconcelos, M., Grodtmann, B., Hauglustaine, D. A., Heil, A., Hoelzemann, J. J., Isaksen, I. S. A., Kaurola, J., Knorr, W., LadstaetterWeissenmayer, A., Mota, B., Oom, D., Pacyna, J., Panasiuk, D., Pereira, J. M. C., Pulles, T., Pyle, J., Rast, S., Richter, A., Savage, N., Schnadt, C., Schulz, M., Spessa, A., Staehelin, J., Sundet, J. K., Szopa, S., Thonicke, K., van het Bolscher, M., van Noije, T., van Velthoven, P., Vik, A. F., and Wittrock, F.: REanalysis of the TROpospheric chemical composition over the past 40 years, A long-term global modeling study of tropospheric chemistry funded under the 5th EU framework programme EU-Contract No. EVK2-CT-2002-00170, Tech. rep., TNO, 2007.

Shao, M., Zhang, Y., Zeng, L., Tang, X., Zhang, J., Zhong, L., and Wang, B.: Ground-level ozone in the Pearl River Delta and the roles of $\{\mathrm{VOC}\}$ and $\mathrm{NO}_{x}$ in its production, J. Environ. Manage., 90, 512-518, doi:10.1016/j.jenvman.2007.12.008, 2009.

Spurr, R. J. D.: LIDORT V2PLUS: a comprehensive radiative transfer package for UV/VIS/NIR nadir remote sensing, Proc. SPIE, 5235, 89-100, doi:10.1117/12.511103, 2004.

Stavrakou, T., Müller, J.-F., De Smedt, I., Van Roozendael, M., Kanakidou, M., Vrekoussis, M., Wittrock, F., Richter, A., and Burrows, J. P.: The continental source of glyoxal estimated by the synergistic use of spaceborne measurements and inverse modelling, Atmos. Chem. Phys., 9, 8431-8446, doi:10.5194/acp-98431-2009, 2009.

Valin, L. C., Russell, A. R., and Cohen, R. C.: Variations of OH radical in an urban plume inferred from $\mathrm{NO}_{2}$ column measurements, Geophys. Res. Lett., 40, 1856-1860, doi:10.1002/grl.50267, 2013.

van Donkelaar, A., Martin, R. V., Leaitch, W. R., Macdonald, A. M., Walker, T. W., Streets, D. G., Zhang, Q., Dunlea, E. J., Jimenez, J. L., Dibb, J. E., Huey, L. G., Weber, R., and Andreae, M. O.: Analysis of aircraft and satellite measurements from the Intercontinental Chemical Transport Experiment (INTEX-B) to quan- 
tify long-range transport of East Asian sulfur to Canada, Atmos. Chem. Phys., 8, 2999-3014, doi:10.5194/acp-8-2999-2008, 2008.

Volkamer, R., Platt, U., and Wirtz, K.: Primary and Secondary Glyoxal Formation from Aromatics: Experimental Evidence for the Bicycloalkyl-Radical Pathway from Benzene, Toluene, and p-Xylene, J. Phys. Chem. A, 105, 7865-7874, doi:10.1021/jp010152w, 2001.

Volkamer, R., Spietz, P., Burrows, J., and Platt, U.: High-resolution absorption cross-section of glyoxal in the UV-vis and $\{$ IR $\}$ spectral ranges, J. Photoch. Photobio. A, 172, 35-46, 2005.

Vrekoussis, M., Wittrock, F., Richter, A., and Burrows, J. P.: GOME-2 observations of oxygenated VOCs: what can we learn from the ratio glyoxal to formaldehyde on a global scale?, Atmos. Chem. Phys., 10, 10145-10160, doi:10.5194/acp-1010145-2010, 2010.

Wang, X., Zhang, Y., Hu, Y., Zhou, W., Lu, K., Zhong, L., Zeng, L., Shao, M., Hu, M., and Russell, A. G.: Process analysis and sensitivity study of regional ozone formation over the Pearl River Delta, China, during the PRIDE-PRD2004 campaign using the Community Multiscale Air Quality modeling system, Atmos. Chem. Phys., 10, 4423-4437, doi:10.5194/acp-10-4423-2010, 2010.

Wild, O., Zhu, X., and Prather, M.: Fast-J: Accurate Simulation of In- and Below-Cloud Photolysis in Tropospheric Chemical Models, J. Atmos. Chem., 37, 245-282, doi:10.1023/A:1006415919030, 2000.

Xue, L. K., Wang, T., Gao, J., Ding, A. J., Zhou, X. H., Blake, D. R., Wang, X. F., Saunders, S. M., Fan, S. J., Zuo, H. C., Zhang, Q. Z., and Wang, W. X.: Ground-level ozone in four Chinese cities: precursors, regional transport and heterogeneous processes, Atmos. Chem. Phys., 14, 13175-13188, doi:10.5194/acp14-13175-2014, 2014.

Zhang, J., Wang, T., Chameides, W. L., Cardelino, C., Kwok, J., Blake, D. R., Ding, A., and So, K. L.: Ozone production and hydrocarbon reactivity in Hong Kong, Southern China, Atmos. Chem. Phys., 7, 557-573, doi:10.5194/acp-7-557-2007, 2007.

Zhang, Q., Streets, D. G., Carmichael, G. R., He, K. B., Huo, H., Kannari, A., Klimont, Z., Park, I. S., Reddy, S., Fu, J. S., Chen, D., Duan, L., Lei, Y., Wang, L. T., and Yao, Z. L.: Asian emissions in 2006 for the NASA INTEX-B mission, Atmos. Chem. Phys., 9, 5131-5153, doi:10.5194/acp-9-5131-2009, 2009.

Zhang, Y., Su, H., Zhong, L., Cheng, Y., Zeng, L., Wang, X., Xiang, Y., Wang, J., Gao, D., Shao, M., Fan, S., and Liu, S.: Regional ozone pollution and observation-based approach for analyzing ozone-precursor relationship during the PRIDE-PRD2004 campaign, Atmos. Environ., 42, 6203-6218, doi:10.1016/j.atmosenv.2008.05.002, 2008.
Zheng, J., Shao, M., Che, W., Zhang, L., Zhong, L., Zhang, Y., and Streets, D.: Speciated VOC Emission Inventory and Spatial Patterns of Ozone Formation Potential in the Pearl River Delta, China, Environ. Sci. Technol., 43, 8580-8586, doi:10.1021/es901688e,2009a.

Zheng, J., Zhang, L., Che, W., Zheng, Z., and Yin, S.: A highly resolved temporal and spatial air pollutant emission inventory for the Pearl River Delta region, China and its uncertainty assessment, Atmos. Enviro., 43, 5112-5122, doi:10.1016/j.atmosenv.2009.04.060, 2009b.

Zheng, J., Zheng, Z., Wang, Z., Zhong, L., and Wu, D.: Biogenic VOCs emission inventory and its temporal and spatial characteristics in the Pearl River Delta area, China Environ. Sci., 29, 345-350, 2009c (in Chinese).

Zheng, J., Zheng, Z., Yu, Y., and Zhong, L.: Temporal, spatial characteristics and uncertainty of biogenic $\{\mathrm{VOC}\}$ emissions in the Pearl River Delta region, China, Atmos. Environ., 44, 19601969, doi:10.1016/j.atmosenv.2010.03.001, 2010.

Zhong, L., Louie, P. K., Zheng, J., Yuan, Z., Yue, D., Ho, J. W., and Lau, A. K.: Science-policy interplay: Air quality management in the Pearl River Delta region and Hong Kong, Atmos. Environ., 76, 3-10, 2013.

Zhu, L., Jacob, D. J., Mickley, L. J., Marais, E. A., Cohan, D. S., Yoshida, Y., Duncan, B. N., Abad, G. G., and Chance, K. V.: Anthropogenic emissions of highly reactive volatile organic compounds in eastern Texas inferred from oversampling of satellite (OMI) measurements of HCHO columns, Environ. Res. Lett., 9, 114004, doi:10.1088/1748-9326/9/11/114004, 2014.

Zhu, L., Jacob, D. J., Kim, P. S., Fisher, J. A., Yu, K., Travis, K. R., Mickley, L. J., Yantosca, R. M., Sulprizio, M. P., De Smedt, I., Gonzalez Abad, G., Chance, K., Li, C., Ferrare, R., Fried, A., Hair, J. W., Hanisco, T. F., Richter, D., Scarino, A. J., Walega, J., Weibring, P., and Wolfe, G. M.: Observing atmospheric formaldehyde ( $\mathrm{HCHO}$ ) from space: validation and intercomparison of six retrievals from four satellites (OMI, GOME2A, GOME2B, OMPS) with SEAC ${ }^{4} \mathrm{RS}$ aircraft observations over the Southeast US, Atmos. Chem. Phys. Discuss., doi:10.5194/acp-2016-162, in review, 2016. 